\title{
Simulation of Sugar Cane Harvesting and Transportation in Nakhon Sawan, Thailand
}

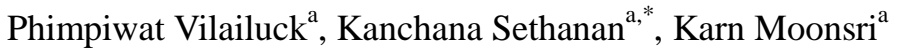 \\ ${ }^{a}$ Research Unit on System Modeling for Industry, Industrial Engineering Department, \\ Faculty of Engineering, Khon Kaen University, Khon Kaen 40002, Thailand \\ *Corresponding Author: ksethanan@gmail.com
}

\begin{abstract}
Transportation is one of the major problems for the sugar industry in Thailand. The loss of opportunity to produce sugar increases with the waiting time of the cane. There are limited resources in the management system for the sugar industry. This research aimed to study decision resource allocation using a simulation model approach to compare the original operating system with the new one, in order to find possible solutions for the time wasted while transporting cane to factories and to allocate trucks per cutting machine at the most appropriate time, including the average value of circuit travelling time. This leads to the ability to make decisions about the allocation of resources throughout the entire season. It also enables the prediction of causes of bottlenecks and problems that may occur in the future, continuous analysis of the current organization, the infrastructure utilized and future demands.
\end{abstract}

Keywords: simulation, sugar cane industry, harvesting.

\section{Introduction}

In order to respond to customer needs quickly and satisfactorily with reasonable cost, the management of the logistics and supply chain in Thailand has an important role in creating advantages in the fiercely competitive business world.

Because Thailand is an industrial farming country which has developed sequentially, there are many different types of agricultural exports such as rubber, cassava, sugar cane etc. Thailand also has a suitable environment for cultivation and most of the Thai population is principally involved in cultivation. Thus, the expansion of agricultural business has a huge effect on the economy of the country, especially sugarcane cane, an important Thai crop which is used as a raw material for sugar production. Considering the process of harvesting and transportation of cane to the sugar factory, each year, approximately 60 to 70 million tons of cane are harvested and transported, which needs a lot of harvest laborers, tractors and trucks. However there are still problems in terms of managing the logistics, harvesting and transport that can accommodate various forms of transport and harvesting in each different area. As a result, the efficiency of the processes still remains low, with high costs for harvest and transportation. Sugarcane harvesting using a cutting machine is an approach to resolve the labor shortage. The sugarcane cutting machine will cut and chop sugarcane into pieces, then transport and put it into a sugarcane truck running parallel with the harvesters in the field. It is not necessary to burn the sugarcane before harvesting, and transporting to factory to maintain the quality of sugar. This process also reduces air pollution problems. A recent study found that a cutting machine is still not effective because the majority of cutting machines' working time is lost while waiting for trucks to return from the sugar factory. As a result, the volume of cane cut per day is still low.

The purpose of this research is to reduce costs and improve the effectiveness of using a cane dump cart by testing the performance of the cutting machine and the truck, using tractors and dragging the cane dump cart to assist in transport. All time variables involved in the process of harvesting and transporting, are measured, and the results tested in depth. State analysis is performed using the simulation of harvesting and transporting program, Arena by "Rockwell Software", to improve the simulation 
process of harvesting and transporting to be as close the real situation as possible. Improving this process will reduce the cost of cane production in Thailand.

\section{Related Literature on Sugar Supply Chain}

In Thailand, the cost of sugarcane harvesting and transportation constitutes a significant portion of the total sugarcane production cost. In order to reduce the total cost, it is necessary to clarify the current shortcomings of the harvesting and transportation processes ${ }^{(5)}$. This operation must be carefully planned and coordinated to avoid the waste of valuable resources. Simulation has been applied to gain insights into the relations between the various processes, the presence of bottlenecks and their causes and at the same time to optimize the resources allocated to the operation as a whole ${ }^{(2)}$.

Long delays between harvesting and milling of sugarcane leads to deterioration in the quality of sugarcane. Simulation modelling was chosen as an appropriate means of analyzing the harvesting and delivery system with a view to reducing these delays. A sensitivity analysis was conducted on an initial harvesting and transport model of a particular mill and the area supplying it and it was concluded that it was necessary to integrate this model with a mill yard model, include limitations on transport availability and model individual farms ${ }^{(3)}$.

Before being harvested sugar cane is burnt in the fields and then cut and carried to the processing plant. After burning, the cane must be processed within 15 days, otherwise the saccharose in it transforms into ethanol and the cane has to be discarded. They present a simulation algorithm for scheduling the operations and planning the resources, in such a way that the lapse of time between end of burning and processing is minimized. That algorithm can be used as a basis for a decision support system ${ }^{(7)}$. Muchow assesses the sensitivity of these responses to crop class and age distribution at harvest, using the Mossman mill region as a case study. Analyses were conducted to assess the consequences of different number of ratoons before ploughing out various fixed crop ages at harvest; and the advantages of fallowing before planting compared to ploughout and immediate replant. Productivity and profitability were found to be sensitive to modifications in model input parameters and constraints ${ }^{(6)}$.

Efficient production of sugar from sugarcane requires integration of growing, harvesting, transport, milling, and marketing. While research targeted to each of these sectors has added significant value in the past, further gains are limited, giving rise to an increasing focus on whole of systems research for the industry to maintain its international competitiveness. A major whole of industry issue is the need to take advantage of geographical, temporal, and crop characteristic differences in sugar yields. Through capturing most of this variability, a methodology was developed that allowed the assessment of profitability benefits from alternative harvest date of cane options throughout a mill region ${ }^{(4)}$.

An interactive optimization system for planning bulk deliveries was implemented by Suiker Unie, a farming cooperative that processes about 60 percent of the Dutch sugar beet crop. The bulk delivery problem differs in several aspects from the standard multi-depot vehicle-routing problem: trucks deliver full loads to each customer and can reload at any one of five factories ${ }^{(8)}$.

And Babic was proposed the process of aircraft refuelling using refuelling trucks at an airport. The problem which arises is to determine the minimum number of refuelling trucks and their routes for the given demand (schedule and fuel quantities). The constraint is that there is no aircraft departure delay due to the refuelling process. The optimum solution is found here using the branch-and-bound technique ${ }^{(1)}$.

In this research, transportation devices used for transferring sugar cane from the fields to mills include 10 wheel-trucks, tractors, and cane dump carts. This paper focuses on an important practical and theoretical problem: where, when and how to retrieve sugar cane from the fields to mills. Computer simulation is used as model for recommending the reduction of costs and improving the effectiveness.

\section{Description of the System}

\subsection{Working Models of the Cutting Machine}

The experiment in this research was to harvest sugar cane comparing two cutting machine models. The details are as follows:

1. Original model: A cutting machine + trucks,

2. New model: A cutting machine + tractors + cane dump carts + trucks.

Trucks must convey cane to a sugar factory. While one truck is running out to the factory, another truck will replace the previous truck. The task of the cutting machine 
is, to work continuously and work with maximum efficiency. The work of a cutting machine and trucks is shown in Figure 1.

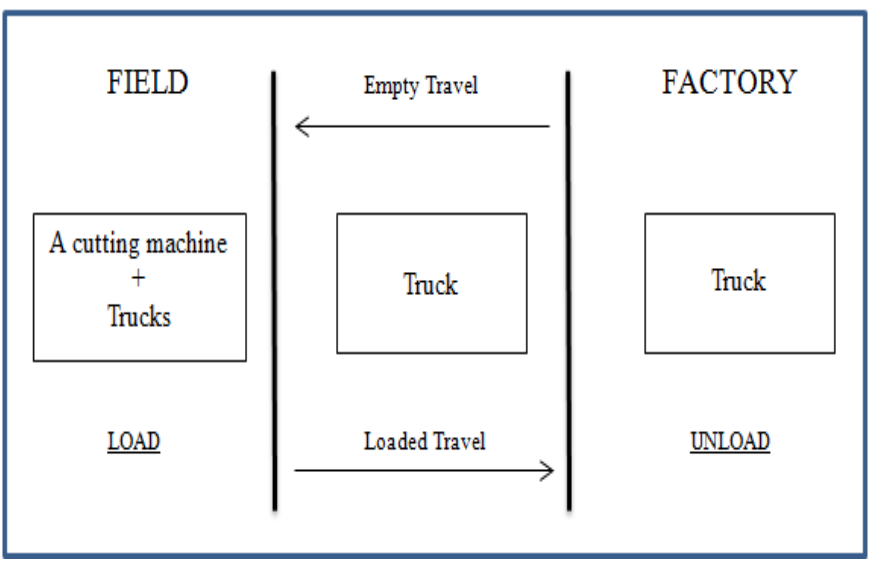

Fig. 1. Original Sugar Cane Transportation System

In the new model, to work continuously with maximum efficiency, the cane dump cart will work together with trucks instead of parking trucks.

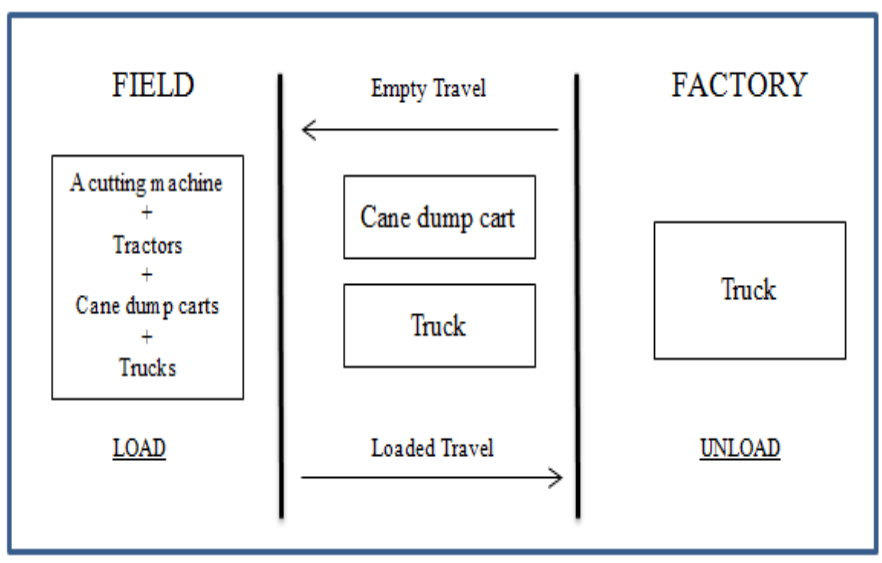

Fig. 2. New Sugar Cane Transportation System

If the cane dump cart becomes full in any cutting round, then, it will unload into a truck. Another truck will replace the previous truck. The operation of a cutting machine + tractors + cane dump cart + trucks is shown in Figure 2.

\subsection{Advantages and Disadvantages of each Working Model}

Advantages and disadvantages of the original and new model are summarized in Table 1 and Table 2 respectively.
Table 1. The advantages and disadvantages of the original system.

\begin{tabular}{|l|}
\hline Advantages \\
- No double handling. \\
- It is not necessary to purchase an \\
additional cane dump cart and tractors. \\
Disadvantages \\
- Truck causes ground compaction. \\
- The truck is unable to enter wet area. \\
- The collaboration of trucks and cutting \\
machine wastes more fuel. \\
machine. \\
It causes cutting machine waiting time for \\
trucks to return.
\end{tabular}

Table 2. The advantages and disadvantages of the new system.

\section{Advantages}

- It can solve problems of compressed soil from trucks.

- It can enter into wet areas.

- It saves more truck fuel working with the cutting machine.

- It reduces the number of trucks used per cutting machine.

- It solves the problem of waiting time for trucks.

\section{Disadvantages}

- The system causes double handling.

- It is necessary to purchase additional cane dump carts and tractor.

- It causes higher budget to maintain the machine.

\section{Contents of the Simulation Model}

\subsection{Conceptual}

This section presents the management logistics for the simulation for the two forms of harvesting and transporting by finding the amount of required equipment and resources, such as the required trucks and the percentage truck use, the number of tractors and cane dump carts required, and sugarcane (tons / day).

Each form needs a simulation model, which requires variables. Thus, the field data of the actual original form of 
operation of the cutting machine + truck was collected, including the new work form of cutting machine + cane dump cart + truck + tractors. Both models have hypotheses in run simulation mode which are:

1. The number of trucks, cane dump carts, and tractors are sufficient,

2. The average plot size is 15 rais (rai $=2 / 5$ acre),

3. The cane density of

- 10 tonnes / rai is equivalent to $10 \mathrm{~kg} / \mathrm{m}$

- 15 tonnes / rai is equivalent to $15 \mathrm{~kg} / \mathrm{m}$,

4. The cutting speed is $6 \mathrm{~km} /$ hour,

5. The work schedule is 120 days and

6 . The working time is 12 hours a day.

\subsection{In Practice}

In this research, the $12^{\text {th }}$ version license of Arena Simulation Software on Windows Experience Index: Intel® Pentium ${ }^{\circledR} 4$ CPU $2.80 \mathrm{GHz} \quad 2.79 \mathrm{GHz} \quad 32$-bit Operating System was used as a tool for creating a harvest model.

Initially, the simulated situation was designed by the research team which needed to study the process of actual harvests including essential data for the different models. The simulation modeling process was divided into 2 parts, harvesting process and transportation process. These are shown in Figures 3 and 4 respectively.

\section{Results}

From the development of the simulation models and different data received from fieldwork trials, the result of logistics management of both the harvesting and transporting processes were obtained by finding the quantity of required equipment and resources, such as the number of trucks required and the percentage of truck use, number of tractors required and cane dump carts, and the quantity of sugarcane (tons / day) in the harvest process for each model. These are shown in Tables 3, 4, 5, 6 and 7 respectively.

Table 3. Original model: One cutting machine + trucks

\begin{tabular}{|c|c|c|c|c|}
\hline $\begin{array}{c}\text { Density of } \\
\text { sugar cane } \\
\text { (tonnes/rai*) }\end{array}$ & \multirow{2}{*}{$\begin{array}{c}\text { Number of } \\
\text { cutting } \\
\text { machine }\end{array}$} & $\begin{array}{c}\text { Amount of } \\
\text { sugar cane } \\
\text { (tonnes) }\end{array}$ & \multicolumn{2}{|c|}{$\begin{array}{c}\text { Number of } \\
\text { trucks }\end{array}$} \\
\cline { 3 - 5 } & 1 & 375.21 & 13.750 & 19 \\
\hline 10 & 1 & 498.62 & 14.750 & 23 \\
\hline 15 & 1 & & & \\
\hline
\end{tabular}

$*$ rai $=2 / 5$ acre

Table 4. New model: One cutting machine + tractors + cane dump cart + trucks

\begin{tabular}{|c|c|c|c|c|c|c|}
\hline \multirow{2}{*}{$\begin{array}{c}\text { Density } \\
\text { of sugar } \\
\text { cane } \\
\text { (tonnes/ } \\
\text { rai*) }\end{array}$} & \multirow[t]{2}{*}{$\begin{array}{l}\text { Number } \\
\text { of } \\
\text { cutting } \\
\text { machine }\end{array}$} & \multirow[t]{2}{*}{$\begin{array}{c}\text { Amount } \\
\text { of sugar } \\
\text { cane } \\
\text { (tonnes) }\end{array}$} & \multicolumn{2}{|c|}{$\begin{array}{l}\text { Number of } \\
\text { tractors and } \\
\text { cane dump } \\
\text { carts }\end{array}$} & \multicolumn{2}{|c|}{$\begin{array}{c}\text { Number of } \\
\text { trucks }\end{array}$} \\
\hline & & & Avg. & Max. & Avg. & Max. \\
\hline 10 & 1 & 395.04 & 1.348 & 3 & 5.575 & 11 \\
\hline 15 & 1 & 519.22 & 1.454 & 3 & 6.975 & 15 \\
\hline
\end{tabular}

$*$ rai $=2 / 5$ acre

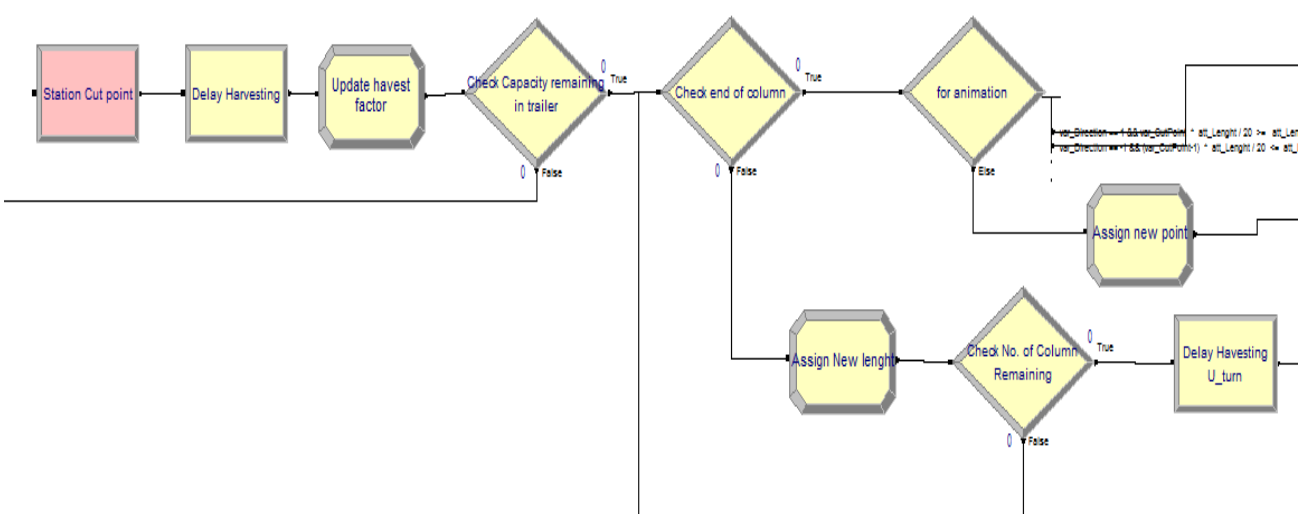

Fig. 3. A part of simulation model of the harvesting process 


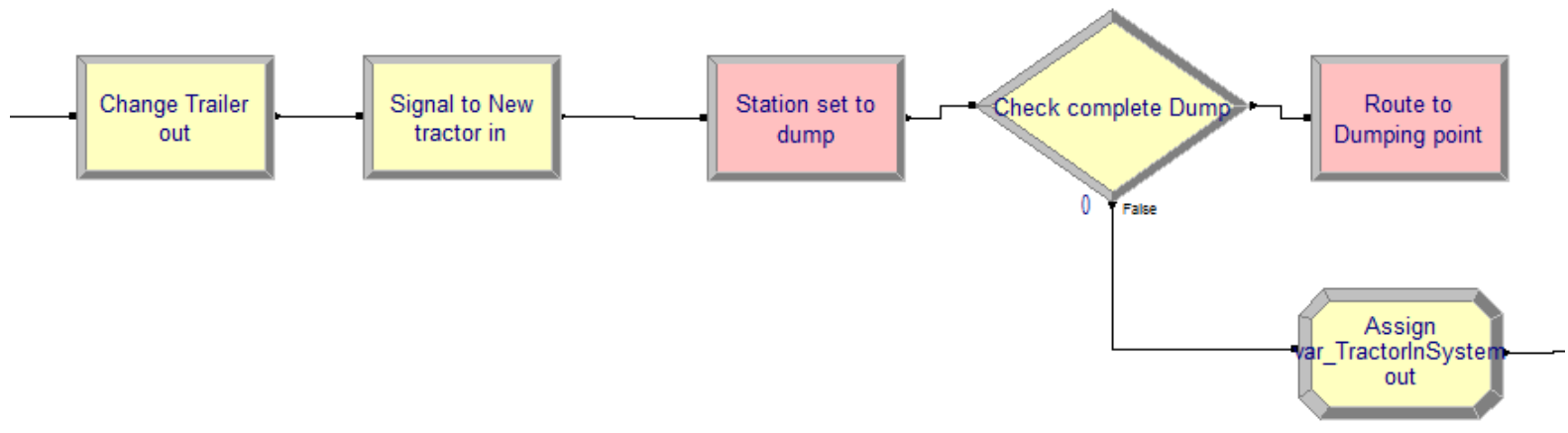

Fig. 4. A part of simulation model of the transport process

Table 5. Number of trucks in the original model

\begin{tabular}{|c|c|c|c|}
\hline $\begin{array}{l}\text { Density of } \\
\text { sugar cane }\end{array}$ & $\begin{array}{c}\text { Number of } \\
\text { trucks }\end{array}$ & $\%$ trucks & $\begin{array}{c}\% \text { cumulative } \\
\text { trucks }\end{array}$ \\
\hline \multirow[t]{19}{*}{ 10tonnes/rai* } & 1 & 5.11 & 5.11 \\
\hline & 2 & 5.34 & 10.45 \\
\hline & 3 & 6.09 & 16.54 \\
\hline & 4 & 6.44 & 22.98 \\
\hline & 5 & 6.88 & 29.86 \\
\hline & 6 & 7.65 & 37.51 \\
\hline & 7 & 8.34 & 45.85 \\
\hline & 8 & 9.13 & 54.98 \\
\hline & 9 & 9.44 & 64.42 \\
\hline & 10 & 9.78 & 74.20 \\
\hline & 11 & 5.96 & 80.16 \\
\hline & 12 & 5.54 & 85.70 \\
\hline & 13 & 4.71 & 90.41 \\
\hline & 14 & 3.13 & 93.54 \\
\hline & 15 & 2.01 & 95.55 \\
\hline & 16 & 1.79 & 97.34 \\
\hline & 17 & 1.04 & 98.38 \\
\hline & 18 & 0.96 & 99.34 \\
\hline & 19 & 0.66 & 100.00 \\
\hline
\end{tabular}

$*$ rai $=2 / 5$ acre

\section{Conclusions}

The development of cane harvesting and transportation simulation can be summarized as follows. If the plot has a greater density of cane, it will result as follows:

- The amount of sugarcane will be increased if the sugarcane plot has a greater density,

- The number of tractors, cane dump carts and trucks used increases, if the sugarcane plot has a greater density. However, in any form of cut, if the number of cane dump carts, tractors and number of trucks are equal between the very dense plots and less dense plots, it is found that the use of resources in the sugarcane harvest plots is very high,

Table 5. Number of trucks in the original model (next)

\begin{tabular}{|c|c|c|c|}
\hline $\begin{array}{l}\text { Density of } \\
\text { sugar cane }\end{array}$ & $\begin{array}{c}\text { Number of } \\
\text { trucks }\end{array}$ & $\%$ trucks & $\begin{array}{c}\% \text { cumulative } \\
\text { trucks }\end{array}$ \\
\hline \multirow[t]{23}{*}{15 tonnes/rai* } & 1 & 4.17 & 4.17 \\
\hline & 2 & 4.34 & 8.51 \\
\hline & 3 & 5.09 & 13.60 \\
\hline & 4 & 5.44 & 19.04 \\
\hline & 5 & 5.88 & 24.92 \\
\hline & 6 & 6.65 & 31.57 \\
\hline & 7 & 7.34 & 38.91 \\
\hline & 8 & 7.13 & 46.04 \\
\hline & 9 & 7.44 & 53.48 \\
\hline & 10 & 6.78 & 60.28 \\
\hline & 11 & 5.96 & 66.22 \\
\hline & 12 & 5.54 & 71.76 \\
\hline & 13 & 4.71 & 76.47 \\
\hline & 14 & 4.13 & 80.60 \\
\hline & 15 & 4.01 & 84.61 \\
\hline & 16 & 3.79 & 88.40 \\
\hline & 17 & 3.04 & 91.44 \\
\hline & 18 & 2.96 & 94.40 \\
\hline & 19 & 2.66 & 97.06 \\
\hline & 20 & 1.09 & 98.15 \\
\hline & 21 & 1.32 & 99.47 \\
\hline & 22 & 0.51 & 99.98 \\
\hline & 23 & 0.02 & 100.00 \\
\hline
\end{tabular}

but can be more effective than less dense sugarcane. Therefore, companies should have appropriate exploration of harvesting, size and shape of sugarcane plots. This saves resources and reduces the cost of harvesting, with higher efficiency. 
Further developments require integration of the proposed methodology with the simulation models to add optimization algorithm into its operation. Even though this paper is focused on sugar cane, we believe that the proposed methodology would apply to other agriculture industries with complex supply chain management.

Table 6. Number of trucks in the new model

\begin{tabular}{|c|c|c|c|}
\hline $\begin{array}{l}\text { Density of } \\
\text { sugar cane }\end{array}$ & $\begin{array}{c}\text { Number of } \\
\text { trucks }\end{array}$ & $\%$ trucks & $\begin{array}{c}\% \text { cumulative } \\
\text { trucks }\end{array}$ \\
\hline \multirow[t]{11}{*}{ 10tonnes/rai } & 1 & 5.53 & 5.53 \\
\hline & 2 & 10.92 & 16.45 \\
\hline & 3 & 11.06 & 27.51 \\
\hline & 4 & 10.83 & 38.35 \\
\hline & 5 & 11.04 & 49.38 \\
\hline & 6 & 10.94 & 60.32 \\
\hline & 7 & 10.92 & 71.24 \\
\hline & 8 & 10.92 & 82.16 \\
\hline & 9 & 10.47 & 92.64 \\
\hline & 10 & 6.27 & 98.91 \\
\hline & 11 & 1.09 & 100.00 \\
\hline \multirow[t]{15}{*}{15 tonnes/rai } & 1 & 4.07 & 4.07 \\
\hline & 2 & 8.35 & 12.42 \\
\hline & 3 & 8.47 & 20.89 \\
\hline & 4 & 8.44 & 29.33 \\
\hline & 5 & 8.48 & 37.81 \\
\hline & 6 & 8.37 & 46.17 \\
\hline & 7 & 8.49 & 54.66 \\
\hline & 8 & 8.35 & 63.02 \\
\hline & 9 & 8.48 & 71.50 \\
\hline & 10 & 8.37 & 79.87 \\
\hline & 11 & 8.37 & 88.23 \\
\hline & 12 & 7.12 & 95.35 \\
\hline & 13 & 3.85 & 99.20 \\
\hline & 14 & 0.77 & 99.98 \\
\hline & 15 & 0.02 & 100.00 \\
\hline
\end{tabular}

$*$ rai $=2 / 5$ acre

Table 7. Number of cane dump carts in the new model

\begin{tabular}{cccc}
\hline $\begin{array}{c}\text { Density of } \\
\text { sugar cane }\end{array}$ & $\begin{array}{c}\text { Number of } \\
\text { cane dump } \\
\text { carts }\end{array}$ & $\begin{array}{c}\text { \% cane dump } \\
\text { cart }\end{array}$ & $\begin{array}{c}\text { \% cumulative } \\
\text { cane dump cart }\end{array}$ \\
\hline 10tonnes/rai & 1 & 65.20 & 65.20 \\
& 2 & 34.79 & 100.00 \\
\hline 15 tonnes/rai & 3 & 0.004 & 100.00 \\
& 2 & 56.96 & 56.96 \\
& 3 & 40.68 & 97.65 \\
\hline
\end{tabular}

* rai $=2 / 5$ acre

\section{Acknowledgment}

This work was supported by the Research Unit on System Modeling for Industry, Khon Kaen University, Thailand.

\section{References}

(1) Babic O.: "Optimization of refueling truck fleets at an airport”, Progamon Journals Ltd., 21(6), pp. 479-487, 1987

(2) Diaz JA and Perez IG. : "Simulation and optimization of sugar cane transportation in harvest season", In: Joines JA, Barton RR, Kang K, Fishwick PA, editors. Winter Simulation Conference; [n.p.: n.d.], pp. 1114 1117,2000

(3) Hansen AC, Barnes AJ and Lyne PWL. : "An integrated approach to simulation sugarcane harvest -to-mill delivery", Paper presented at the 1998 ASAE Annual International Meeting Presentation, Paper No.986099,1998

(4) Higgins AJ and Muchow RC. : "Assessing the potential benefits of alternative cane supply arrangement in the Australian sugar industry", Agricultural Systems[serial online], 2003

(5) Kaewtrakulpong, K., Takigawa, T., Koike, M., Hasegawa, H. and Bahalayodhin, B.: "Mechanization for the Improvement of the Sugarcane Harvesting and Transportation System in Thailand: A Case Study in Udon Thani Province", Journal of the Japanese Society of Agricultural Machinery, 70(2), pp. 51-61, 2002

(6) Muchow RC, Higgins AJ, Rudd AV and Ford AW.: "Optimising harvest date in sugar production: A case study for the Mossman mill region in Australia II. Sensitivity to crop age and crop class distribution", Field Crops Research, 57, pp. 243-251, 1998

(7) Semenzato R.: "A simulation study of sugar cane harvesting", Agricultural Systems, 47, pp. 427-437, 1995

(8) Van Vliet A, Boender CGE and Rinnooy Kan AHG.: "Interactive optimization of bulk sugar deliveries", Interfaces, May - June, 22(3), pp. 4-14, 1992 